Andreas Rücker

Research Assistant Technical University of Munich Faculty of Mechanical Engineering Chair of Materials Handling, Material Flow, Logistics (fml) Germany

Jona Rief

Research Assistant Technical University of Munich Faculty of Mechanical Engineering Chair of Materials Handling, Material Flow, Logistics (fml)

Germany

Johannes Fottner

Professor

Technical University of Munich Faculty of Mechanical Engineering Chair of Materials Handling, Material Flow, Logistics (fml) Germany

\section{An investigation of Mean Energy Demand, Performance and Reference Cycles for Stacker Cranes}

Automated storage and retrieval systems (AS-RS) are commonly used in intralogistic facilities and are often operated by stacker cranes. These stacker cranes are used in high-bay warehouses to move small load carriers, pallets and special load carriers. This paper presents an approach for the determination of the mean energy demand of stacker cranes, using a reference cycle. The examanition of the reference cycles is based on a large scale simulation experiment with randomly generated stacker crane and rack configurations and operation tasks. The results permitted an analysis of the correlations between various paramters e.g. energy demand and performance of stacker cranes. Subsequently, three different reference cycles which allow an easy and fast calculation of the mean energy demand are developed and evaluated.

Keywords: Intralogistics, High-bay warehouse, Automated storage and retrieval system, Stacker crane, Energy demand.

\section{INTRODUCTION}

Stacker cranes (SCs) are large machines which move small load carriers and pallets in high-bay warehouses. These high-bay warehouses are one typical component of intralogistic facilities. The energy demand during the operation of SCs is influenced by a huge number of variable effects. These effects are often coupled and influence each other. Therefore the analytical calculation of the energy demand is complex and sometimes linked to detailed simulation models. The main idea is to find reference cycles which allow the calculation and evaluation of the overall mean energy demand of different SCs and storage configurations.

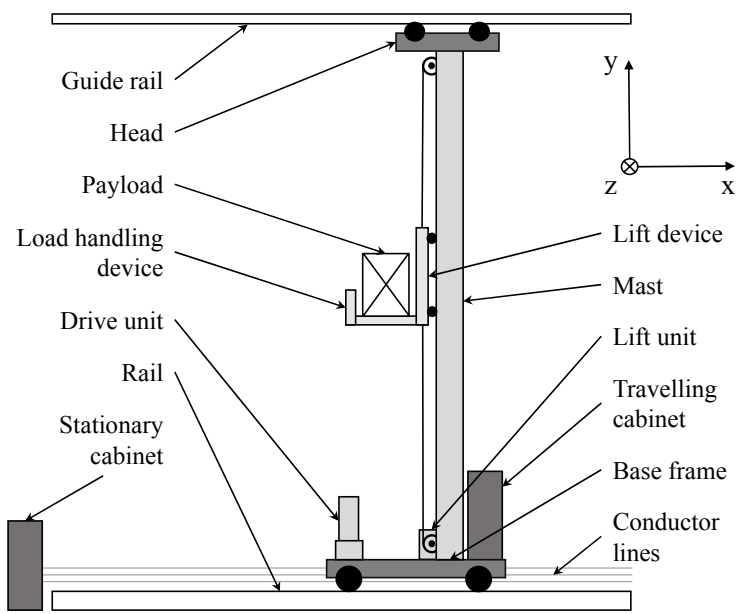

Figure 1. Scheme of a rack feeder (compare [17])

Received: December 2019, Accepted: February 2020

Correspondence to: Andreas Rücker, M.Sc.

Chair of Materials Handling, Material Flow, Logistics

Boltzmannstraße 15, 85748 Garching, Germany

E-mail: andreas.ruecker@tum.de

doi: $10.5937 /$ fme2002307R

(C) Faculty of Mechanical Engineering, Belgrade. All rights reserved
This paper presents an approach, which determines and evaluates reference cycles. Subsequently, the reference cycles are tested for their use in the determination of the mean energy demand. Such reference cycles are already in use to calculate the mean travel time of SCs $[6,22]$. In this paper we distinguish between miniload stacker cranes (MSCs) for small load carriers and pallet stacker cranes (PSCs), as they differ fundamentally in their mass ratios. Figure 1 shows a typical scheme of a rack feeder with the nomenclature used in the paper. The main components are the base frame, the mast, the head, the lift device and the drives. A rack feeder has two main drives - for the horizontal and vertical movement of the payload. The main drives are electrically connected via an intermediate circuit.

\section{LITERATURE}

The determination of the travel time of SC has been the subject of a large number of investigations in the past. Starting with the basics of travel time metrics in [3], several papers have been presented in recent years. A detailed review of the literature concerning $\mathrm{SC}$ was presented from Roodbergen [16]. The most recent review paper, though its focus was on the scheduling task, was published in 2016 [2]. In the past, various publications have dealt with the energy demand of SCs. Meneghetti et al. performed various investigations into the strategic parameters that influence energy demand and performance [11-14]. Schulz et al. performed an investigation of isoenergetic shelves in automatic small parts warehouses [19]. Ertl presented a simplified way of calculating the mean energy demand of MSCs [5]. Lerher et al. gave an initial method for calculating the energy efficiency of MSCs [10]. A method for the benchmarking of different types of AS-RS was presented by Stöhr et al. [21]. In their work they suggested the use of the standard double cycle from 
VDI 3561 [22] and other standards to compare three different types of AS-RS.

The optimization of energy efficiency in intralogistics was part of the research work from Hafner and Lottersberger $[8,9]$. A new approach for a multi criteria optimization of the investment expenses, cycle times and $\mathrm{CO} 2$ emissions for automated storage and retrieval systems was presented by Rajkovic et al. [15].

PSCs have not been studied in such detail in the past. Various standards define a calculation scheme for the mean travel time and the throughput of an SC. These standards $[6,22]$ use reference cycles to perform a standardised calculation of the mean travel time. Azzi et al. proposed a method to calculate a reference quadruple cycle via a Monte Carlo simulation [1]. None of the existing approaches is combining the energy demand and throughput analysis of MSC and PSC with an approach for a reference cycle for the mean energ demand.

\section{MATERIALS AND METHODS}

SCs can be operated with different operation modes. The basic mode is the single cycle mode. In a single cycle, the SC performs a store or retrieve task regarding one item. In a double cycle, the SC performs a store task and then a retrieve task. In the complex quadruple cycle, two store and two retrieve tasks are combined into one cycle. Quadruple cycles can be performed with double load handling device SC. Examples for the movement of the SC within different cycle types are shown in Figure 2. In our investigation, we used single and double cycles, and the Input /Output point is located in the lower left corner of the rack.



Figure 2. Examples for different cycle types (compare [17])

In this paper, we use the basic approach from Azzi et al. of taking a large number of random cycles to investigate not the mean travel time, but the mean energy demand and the performance of various SC configurations. The goals are the investigation of the influence of different parameters and the formation of reference cycles. The reference cycles should represent the mean energy demand in the use of various types of SC. Therefore MSCs and PSCs with and without a refeed unit are investigated. The refeed unit allows an SC to feed electrical energy, released during braking, back to the supply network. We use a large-scale simulation experiment to examine the mean energy demand by simulating a large number of random cycles. The layout of the simulation experiment is pictured in Figure 3.

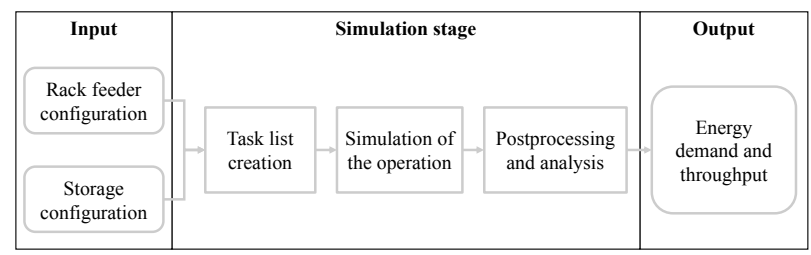

Figure 3. Layout of the simulation study

Initially the SC and storage configuration are randomly generated. The values for the varied parameters are selected between predefined borders via a Latin hypercube sampling (LHS) algorithm [20].

The varied parameters for MSC and PSC and their minimum and maximum values are listed in Table 1. The number of columns and levels define the size of the rack.

Table 1. List of the varied parameters and their maximum and minimum values for MSC and PSC

\begin{tabular}{|l|c|c|c|c|}
\hline \multicolumn{1}{|c|}{ Parameter } & $\begin{array}{c}\text { MSC } \\
\text { min }\end{array}$ & $\begin{array}{c}\text { MSC } \\
\text { max }\end{array}$ & $\begin{array}{c}\text { PSC } \\
\text { min }\end{array}$ & $\begin{array}{c}\text { PSC } \\
\text { max }\end{array}$ \\
\hline $\begin{array}{l}\text { Number of columns } \\
n_{\text {col }}\end{array}$ & 30 & 80 & 20 & 60 \\
\hline $\begin{array}{l}\text { Number of levels } \\
n_{\text {lev }}\end{array}$ & 20 & 40 & 8 & 18 \\
\hline $\begin{array}{l}\text { Acceleration drive } \\
\text { unit } a_{x}\end{array}$ & $2 \mathrm{~m} / \mathrm{s}^{2}$ & $5 \mathrm{~m} / \mathrm{s}^{2}$ & $\begin{array}{c}0.5 \\
\mathrm{~m} / \mathrm{s}^{2}\end{array}$ & $\begin{array}{c}1.5 \\
\mathrm{~m} / \mathrm{s}^{2}\end{array}$ \\
\hline $\begin{array}{l}\text { Acceleration lift unit } \\
a_{y}\end{array}$ & $1 \mathrm{~m} / \mathrm{s}^{2}$ & $3 \mathrm{~m} / \mathrm{s}^{2}$ & $\begin{array}{c}0.2 \\
\mathrm{~m} / \mathrm{s}^{2}\end{array}$ & $\begin{array}{c}1 \\
\mathrm{~m} / \mathrm{s}^{2}\end{array}$ \\
\hline Velocity drive unit $v_{x}$ & $4 \mathrm{~m} / \mathrm{s}$ & $6 \mathrm{~m} / \mathrm{s}$ & $\begin{array}{c}1.5 \\
\mathrm{~m} / \mathrm{s}\end{array}$ & $\begin{array}{c}3.5 \\
\mathrm{~m} / \mathrm{s}\end{array}$ \\
\hline $\begin{array}{l}\text { Velocity lift unit } \\
v_{v} \text { in m/s }\end{array}$ & 1.5 \\
\hline $\begin{array}{l}\text { Efficiency drive and } \\
\text { lift unit } \eta_{x}, \eta_{y}\end{array}$ & 0.4 & $3 \mathrm{~m} / \mathrm{s}$ & $\begin{array}{c}0.5 \\
\mathrm{~m} / \mathrm{s}\end{array}$ & $2 \mathrm{~m} / \mathrm{s}$ \\
\hline Mass base frame $m_{\text {base }}$ & $1.2 \mathrm{t}$ & $2 \mathrm{t}$ & $8 \mathrm{t}$ & $20 \mathrm{t}$ \\
\hline Mass lift unit $m_{L U}$ & $\begin{array}{c}250 \\
\mathrm{~kg}\end{array}$ & $\begin{array}{c}450 \\
\mathrm{~kg}\end{array}$ & $2.5 \mathrm{t}$ & $4.5 \mathrm{t}$ \\
\hline Mass payload $m_{\text {load }}$ & $25 \mathrm{~kg}$ & $75 \mathrm{~kg}$ & $0.5 \mathrm{t}$ & $1.5 \mathrm{t}$ \\
\hline $\begin{array}{l}\text { Storage occupancy } \\
\text { Occ }\end{array}$ & 0.4 & 0.9 & 0.4 & 0.9 \\
\hline $\begin{array}{l}\text { Use of a refeed unit } \\
R U\end{array}$ & 0 & 1 & 0 & 1 \\
\hline
\end{tabular}

The parameters include the main construction parameters such as size of the rack and the SC, the configuration of the brake-energy use, the transported load and the drive speeds. The efficiency values combine electrical and mechanical losses in the drives. Every rack feeder configuration is equipped with an intermediate circuit and is able to use the brake energy of one drive for another drive.

After the creation of the configuration, a task list with random cycles is generated. The storage occupancy is used to create a starting rack layout with stored items and the occupancy is kept relatively constant throughout the simulation. The task list and the configuration data is used to simulate the energy demand and the throughput of the SC for one configuration. For the simulation, a simplified model is used to keep computation time as short as possible. The model is based on the analytical calculation of energy demand in terms of kinetic and potential energy, and various friction-based resistances. For the MSCs and the PSCs 
we used 10000 different configurations each. 5000 configurations are selected via the LHS and the use of a refeed unit is either on or off. For every single configuration, the number of random single and double cycles is calculated via (1)

$$
N_{\text {col }} \cdot N_{\text {lev }} \cdot 1000
$$

Thus, in total we simulated 20000 configurations with several hundred thousand to several million cycles in each configuration. Following the simulation of energy demand and throughput for all configurations and cycles, the data was processed and analysed.

\section{RESULTS}

We analysed two general aspects in the calculated data. First we inspected the different effects of the varied parameters on energy demand and performance. We used the throughput of moved items per hour as an indicator for performance. Secondly the data is used to find reference cycles which meet the overall mean energy demand of the rack feeder. The mean energy demand is calculated as global mean of all drive and lift movements. We have not taken any downtime into account.

\subsection{Effects of single parameters}

We split the results for the MSCs and PSCs and plotted the correlations between the varied parameters and energy demand $E$ and throughput TP. The number in every correlation field represents the correlation coefficient. This coefficient takes values between minus 1 and plus 1.The mass moved in a horizontal direction $m_{x}$ comprises the overall mass of the base frame, mast and lift unit, while the moved mass in vertical direction $m_{y}$ comprises the mass of the lift unit and the load-handling device. The results for the MSCs are shown in Figure 4. The units of the variables are shown in Table 1. Drive acceleration and velocity and the moved masses show a strong dependency on $E$. The effect from $m_{x}$ on TP is caused by the fact that the mass of the mast is scaled according to the number of levels. Therefore we have an increased $m_{x}$ for higher racks and a dependency between $m_{x}$ and TP. Lift acceleration $a_{y}$ and velocity $v_{y}$ have no significant effect on the energy demand. The number of columns and levels define the storage capacity. For increasing numbers, the mean energy demand increases and the throughput decreases.

For the PSCs we found similar correlations which are shown in Figure 5. Due to the changed mass ratios, the sizes of the correlation coefficients change. Accelerations and velocities are smaller than the ones from the MSCs and are less significant in terms of $T P$ and $E$. The ratio of maximum speed to maximum acceleration of an MSC drive can reach 1, whereas this ratio for the PSCs is around 2 and bigger. The influence of the masses on $E$ is slightly higher compared to the MSCs.

$O c c$ has no influence on MSC or PSC configurations because, at occupancy levels between 40 and $90 \%$ the normal operation of the whole storage facility is still possible. Relocations were not taken into account during the simulation.

The use of a refeed unit increases the standby power of an SC. Therefore its use in a real-world application does not always lower the overall energy demand, because if the SC has a lot of downtime with no movement, then the increased standby power causes a general rise in energy demand. For our simulation with no downtime, the general reduction of the mean energy demand is hence obvious.

For the correlations, we used the 5000 configurations without a refeed unit. We also inspected the results with a refeed unit, however the general trends essentially gave a similar picture. With the use of a refeed unit we discovered a general reduction in the mean energy demand. The reduction for the MSC double-cycle configurations are shown in Figure 6. The reduction varies between 3 and $23 \%$. For PSCs and single cycles we found similar results for the reduction of the energy demand.



Figure 4. Correlations for the MSC double cycle configurations without refeed unit and with TP in moved items per hour and $\mathbf{E}$ in $\mathbf{k J}$

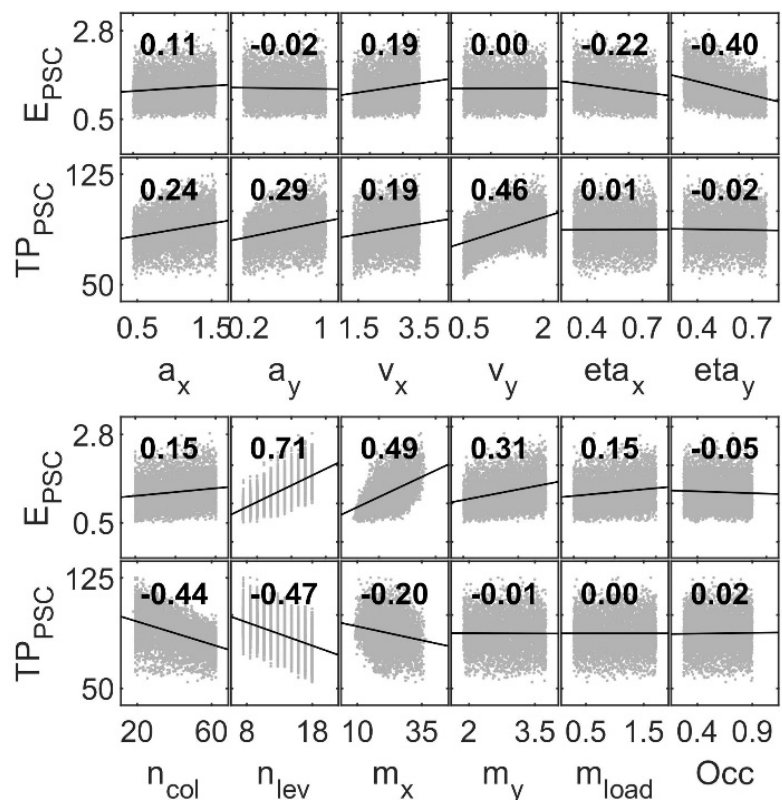

Figure 5. Correlations for the PSC double cycle configurations without refeed unit and with TP in moved items per hour and $\mathrm{E}$ in $\mathrm{MJ}$ 


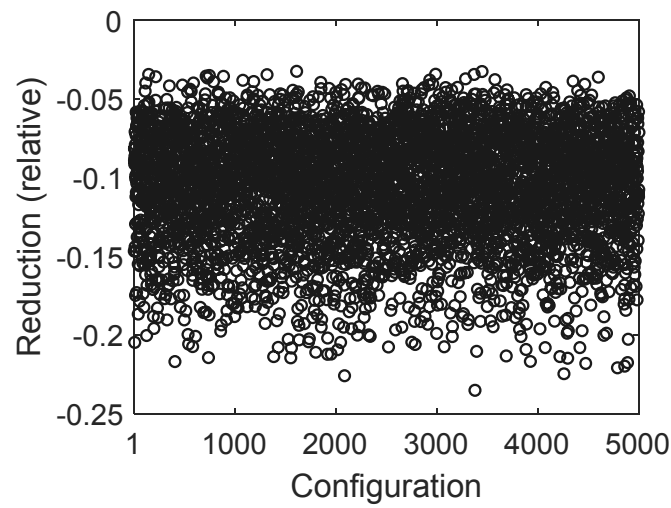

Figure 6. Reduction of the mean energy demand through the use of a refeed unit for MSC double cycle configurations

\subsection{Reference cycles}

In essence, we searched for cycles which had the same energy demand as the overall mean energy demand and called these cycles "reference cycles". A reference cycle allows the quick calculation of the mean energy demand and is also suitable for subsequent experiments, analogously to the way reference cycles are used for the mean cycle-time calculation. Within the scope of this work, we developed the two different calculation approaches "mean" and "interpolation". Overall, we examined three different reference cycles. The mean cycle, the interpolation cycle and the reference cycle proposed in the FEM 9.851 [6]. For the FEM cycle, we used the store and retrieve position from (2).

$$
\begin{aligned}
& \text { Store position: } P_{S}\left(\frac{2}{3} \cdot L, \frac{1}{5} \cdot H\right) \\
& \text { Retrieve position: } P_{R}\left(\frac{1}{5} \cdot L, \frac{2}{3} \cdot H\right)
\end{aligned}
$$

where $L$ is rack length and $H$ is rack length

For the purpose of comparison, we chose the double cycle because this proved to be suitable in previous research work [7]. The presented results are focused on the MSC configurations without a refeed unit. The other configurations were also inspected, but showed no significant differences in their general trend. The overall relative error over the percentage of configurations is shown in the histograms in Figure 7 and Figure 8. Figure. Starting with the mean and the interpolation cycle in Figure 7 we see relative errors of between minus 15 and plus $60 \%$. Although the interpolation shows different results, neither the mean nor the interpolation cycle gave satisfying results.
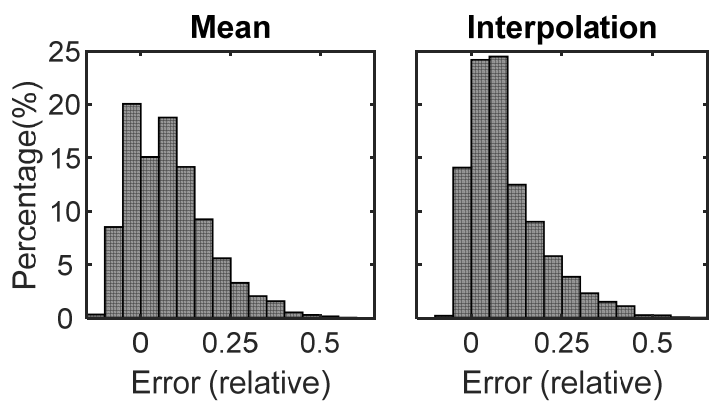

Figure 7. Relative error for the mean and the interpolation cycle for the MSC configurations
Following the results for the relative error of the FEM cycle are presented in Figure 8. Surprisingly the FEM cycle showed much better results, with a maximum relative error of between 0 and $17 \%$. With the FEM cycle, we were able to ensure relatively stable deviations from the mean energy demand.

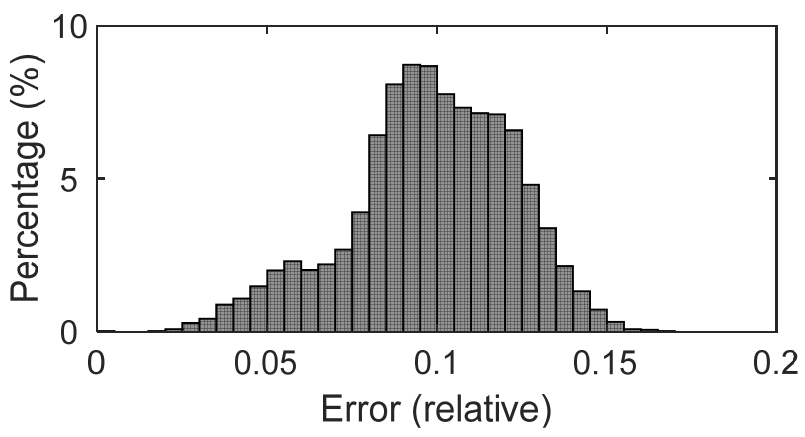

Figure 8. Relative error of the FEM cycle for the MSC configurations

Additionally, the correlation of the simulated mean energy demand and the energy demand of the mean cycle and the FEM cycle is shown in Figure 9. Every dot represents the result for one simulated configuration. The FEM cycle shows clearly lower maximum deviations and differs significantly less than the mean cycle. Using a linear fitting, it would easily be possible to recalculate the overall mean energy demand by using the FEM cycle.

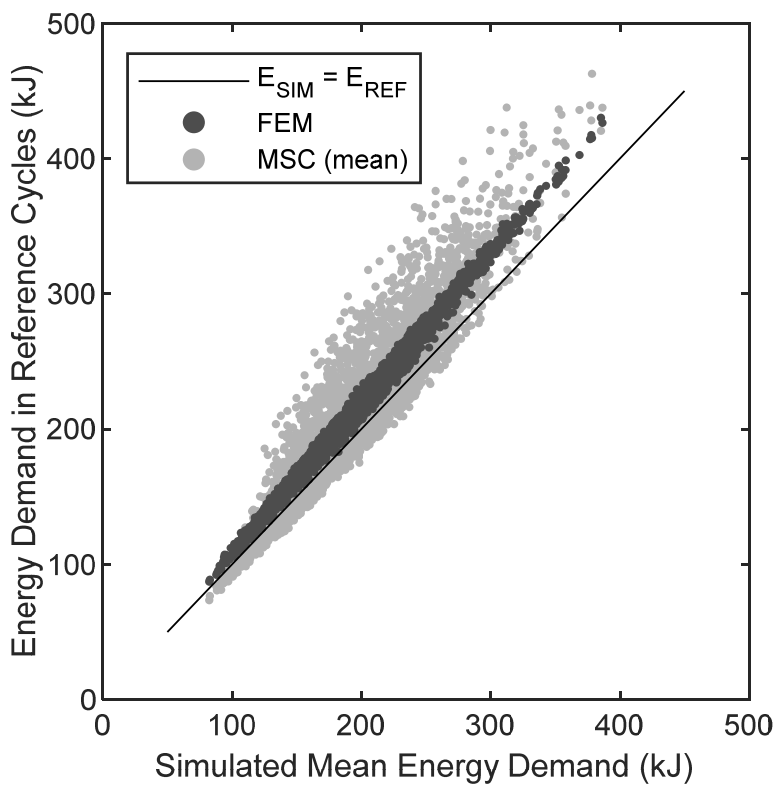

Figure 9. Correlation for the mean energy demand for MSC

Neither cycle was able to beat the FEM cycle for accuracy. Therefore the FEM cycle is currently considered the best solution for a reference cycle. For the first time, a simulation approved reason for using the FEM cycle as reference for energy demand investigations is given. is given.

\section{CONCLUSION}

In the simulation study we analysed single and double cycle operation for MSC and PSC with a large scale simulation experiment. The results from the simulation 
allowed an investigation of the varied parameters and their effect on the mean energy demand and the performance. This allowed important relationships between the parameters to be shown and existing research work was confirmed.

The reference cycles should allow an easy comparison between different types of SC and should be suitable for a good estimation of the mean energy demand. With the FEM cycle as currently best solution for the mean energy demand we found a suitable reference cycle. This cycle can also be used for real life tests of SC.

Our further research tasks in this field will be focused on the application from the gained results to an energy efficiency calculation method. Based on the work of Ertl [4] and Lerher et al. [10] a detailed energy efficiency model for MSC and PSC will be presented in further publications.

\section{ACKNOWLEDGMENTS}

The research has been conducted within the industrielle Gemeinschaftsforschung [collective industrial research] (iGF) project "Entwicklung einer Bewertungsmethodik für die Energieeffizienz eines Regalbediengerätes" (iGF project number $18839 \mathrm{~N}$ ). This project has been funded by the Federal Ministry for Economic Affairs and Energy on the basis of a decision of the German Bundestag [Federal Parliament].

\section{REFERENCES}

[1] Azzi, A., Battini, D., Faccio, M., Persona, A., Sgarbossa, F.: Innovative travel time model for dual-shuttle automated storage/retrieval systems. Computers \& Industrial Engineering 61, No. 3, pp. 600-607, 2011.

[2] Boysen, N., Stephan, K.: A survey on single crane scheduling in automated storage/retrieval systems. European Journal of Operational Research 254, No. 3, 691-704, 2016.

[3] Bozer, Y.A., White, J.A.: Travel-Time Models for Automated Storage/Retrieval Systems. IEE Transactions 37, 329-338, 1984.

[4] Ertl, R.: Energy demand determination and energy efficiency assessment of storage and retrieval machines in automatic small parts warehouses, (German), PhD, Technical University of Munich, 2016.

[5] Ertl, R., Willibald A., G.: Meta-model for calculating the mean energy demand of automated storage and retrieval systems, Logistics Journal, 2016.

[6] European Materials Handling Federation: Performance record for storage and retrieval machines - Cycle times, FEM 9.851, 2003

[7] Fottner J, Rücker A.: Development of an evaluation methodology for the energy efficiency stacker cranes (German), Technical University of Munich; 2019.

[8] Hafner, N., Lottersberger, F.: Energy Efficiency in Material Flow Systems (effMFS), FME Transaction 40, No. 4, pp. 181-186, 2012.
[9] Hafner, N., Lottersberger, F.: Intralogistics systems - optimization of energy efficiency, FME Transaction 44, No. 3, pp. 256-262, 2016.

[10]Lerher, T., Edl, M., Rosi, B.: Energy efficiency model for the mini-load automated storage and retrieval systems, Advanced Manufacturing Technology, 2013.

[11] Meneghetti, A., Monti, L.: Energy Efficient Dual Command Cycles in Automated Storage and Retrieval Systems, Conference Proceedings World Renewable Energy Congress Sweden, 2011.

[12] Meneghetti, A., Monti, L.: Multiple-weight unit load storage assignment strategies for energyefficient automated warehouses, International Journal of Logistics Research and Applications, Volume 17, Issue 4, 2013.

[13] Meneghetti, A., Monti, L.: Sustainable storage assignment and dwell-point policies for automated storage and retrieval systems. Production Planning \& Control: The Management of OperationsVol. 24, No. 6, pp. 511-520, 2013.

[14] Meneghetti, A., Dal Borgo, E., Monti, L.: Rack shape and energy efficient operations in automated storage and retrieval systems, International journal of production research 53, pp. 7090-7103, 2015.

[15] Rajkovic, M., Zrnic, N., Kosanic, N., Borovinsek, M., Lerher, T.: A multi-objective optimization model for minimizing cost, travel time and $\mathrm{CO}_{2}$ emission in an AS/RS, FME Transaction 45, No. 4, pp. 620-629, 2017.

[16] Roodbergen, K.J., Vis, I.F.A.: A survey of literature on automated storage and retrieval systems. European Journal of Operational Research 194, No. 2, pp. 343-362, 2009.

[17]Rücker, A., Fottner, J.: Development of a multicomponent evaluation methodology for the energy efficiency of stacker cranes (German), Logistics Journal Proceedings, 2018.

[18] Rücker, A., Rief, J., Fottner, J.: An investigation of mean energy demand, performance and reference cycles for stacker cranes, Proceedings of the XXIII International Conference on "Material Handling, Constructions and Logistics", Vienna, pp. 197-202, 2019.

[19] Schulz, R., Monecke, J., Zadek, H.: Isoenergetic Shelves of Automatic Small Parts Warehouses. Logistics Journal, 2012.

[20] Siebertz, K., van Bebber, D., Hochkirchen, T.: Statistical design of experiments (German), 2017.

[21] Stöhr, T., Schadler, M. Hafner, N.: Energy efficiency benchmarking concept for diverse automated storage and retrieval systems. Conference Proceedings XXII International Conference on Material Handling, Constructions and Logistics - MHCL, 2017.

[22] Association of German Engineers: Test games for performance comparison and approval of storage and retrieval machines (German), VDI 3561,1973. 
ИСТРАЖИВАЫЕ СРЕДЫЕ ВРЕДНОСТИ ПОТРЕБНЕ ЕНЕРГИЈЕ, ПЕРФОРМАНСИ И РЕФЕРЕНТНИХ ЦИКЛУСА СЛАГАЧКИХ КРАНОВА

\section{А. Рикер, Ј. Риф, Ј. Фотнер}

У објектима са унутрашњом логистиком обично се користе слагачки кранови за аутоматизовано слагање и узимање робе. Слагачки кранови се употребљавају у високо-регалним складиштима за померање малих носача терета, палета и специјалних носача терета. Рад приказује метод за одређивање средње вредности потребне енергије код слагачког крана применом референтног циклуса.

Истраживање референтних циклуса је базирано на великом броју симулација са случајно изабраним краном, конфигурацијом регала и радним задацима. Резултати су омогућили анализу корелација између различитих параметара, као што су нпр. потребна енергија и перформансе крана. Потом су развијена и евалуирана три различита референтна циклуса који омогућавају лако и брзо израчунавање средње вредности потребне енергије. 